\title{
After Marabar: Reading Forster, Robbe-Grillet, Spark
}

\author{
Joseph Hynes
}

Fifty years ago E. M. Forster set forth the basis for interesting and valuable distinctions when, in A Passage to India, he attached importance to the terms "muddle" and "mystery." Both within and well beyond the context of that novel, as I hope to indicate, these terms can be seen to stress what the receiver and potential "connector" makes experience to mean, rather than what an object, person, occurrence may mean in some absolute sense. Forster's distinction is also, then, relativistic: one man's muddle is another man's mystery. Moreover, the distinction emphasizes, relativistically, at least two ways of regarding the unknown or the rationally unexplainable: those of one kind of rationalist and of the supernaturalist, or perhaps those of realist and romantic.

Forster's book and its distinguishing terms are attractive because, albeit negatively, they remind me again of what seems a non-problem or at any rate a not very pressing or interesting problem, and also because, positively, they intimate how to take the initial premises of two kinds of author and therefore how to read two kinds of book. My intention, accordingly, is briefly to put aside (without disposing of) the non-problem, and then to look at two contemporary writers in Forster's terms if not with his eyes, in order to establish the two writers' differences. To perform this dual task should remind us again of Forster's vision as well as clarify our reading of two authors whose books seem well suited to discussion stemming from Forster's terminology. The two writers of prose fiction are Alain Robbe-Grillet and Muriel Spark, and the not very interesting problem is the generic one.

To minimize generic differences here does not imply their lack of importance in the long view, or suggest that I am ungrateful for such terms as tragedy and comedy, epic and lyric, narrative and drama. Rather, while I suspect that generic refinements may eventually lead to fruitful insights into the two writers in question, I maintain that such theoretical buttressing as we have been given to explain away the novel and to fashion in our minds the anti-novel or post-novel fiction seems unconvincing as support for something absolutely new, and radically unhelpful as means to reading what it is intended to elucidate. For my money, it is immensely more valuable to use labels like novel and novella to cover longer and shorter prose fiction, and to accommodate liberal humanistic psychology, post-modern anti-novelistic phenomenology, and other such nomenclature within the retained, maybe too simple, but eminently serviceable categories.

If $\mathrm{I}$ am right in my readings and inclinations, then, the realm of the novel is very broad indeed, and not at all limited to nineteenth-century social and psycho- 
logical realism, whenever and wherever written. While I do not wish to linger over this point (which I should not have raised at all were it not so insistently in the air that we have seen the end of the novel and its possibilities), I think I may clarify this issue by observing that I seem to read a good many more novels carefully, and without confusing their characteristics with those of other books, when I think of these books as varieties of "novel," than when I regard them as examples of Novel, Romance, Fantasy, Anti-Novel, etc. We have indeed to allow for such differences as are suggested by these capitalized headings, but I for one can make such allowances more readily within the realm of novel than by regarding, say, A Portrait of the Artist as a Young Man, Ulysses, Tom Jones, Bleak House, Tristram Shandy, Pale Fire and Watt as intrinsically distinct kinds of writing. For me, then, at least where prose fiction is concerned, generic distinctions do not constitute a theoretical problem in criticism of the contemporaneous.

What may be called a problem is exactly what has always been a problem: establishing the different conventions, suppositions, literary moves, all of them recognizably novelistic, which go into distinctions among texts. In other words, differences between Moll Flanders and Tristram Shandy are no more differences of kind than are differences between either of these novels and Robert Coover's Universal Baseball Association, Inc., J. Henry Waugh, Prop. All of these books are narratives, stories or occurrences told (if only by a voice or voices); all are prose; all are unified indications of morally serious views of reality; all are peopled or charactered, however variously, to thematically discussable ends. The problem is therefore that of reading each book on its own terms, once we have got over the temptation to establish separate generic compartments encouraged by blurb-writers and their academic counterparts. And the need to read carefully and inductively extends, obviously, to those who cope with Robbe-Grillet and Spark.

The reason for including Robbe-Grillet in this discussion is his arguing "for a new novel," intrinsically unlike nineteenth-century psychological realism. Then in his practice-say, in La Maison de Rendez-vous-he demonstrates what he means by his new prose fiction, his phenomenological art. He gives us a sharply visualized set of happenings or detailed descriptions of what appear to be places and characters; he refuses to give us answers to fairly standard questions aroused by habits drilled into readers of nineteenth-century fiction. That is, he frustrates efforts to find out who is (are) narrating; what audience(s) may be specifically addressed; where the book's happenings may be understood to have occurred; when, in relation to what seem like events, the narrative is being delivered; whether this or that speaker is recording history, or dreaming, or remembering interiorly, or supposing what might be or have been, as either history or literature; and how the items narrated may be related to one another chronologically, causally, "significantly," psychologically, morally, socially or otherwise adverb- 
ially. Here is a whole lot of stuff, Robbe-Grillet seems to be saying, which may be thought of as happening inside and/or outside the mind(s) of one or more thinker-speakers, and all I've done is arrange it in precisely etched word-patterns out of which you readers will make whatever you like. But don't lay your meanings to anything I've imposed upon you. I invite you to view my etchings; you make of them what you can or will or must. Psychology is dead; long seem to live phenomenology.

This effort to succeed where Zola failed makes for remarkable differences from Dickens or Conrad, but it does not make for fundamental differences, since even in Robbe-Grillet we find such typical novelistic traits as incident, setting, prose narration, and even point of view and characterization of a specially incipient sort. Unreliability of narration, character, sequential occurrence, motivation, outcome does not preclude narrative seriousness, adroitness of depiction, masterful illusion-making, and clarity of the work's direction and purport. The phenomenologist's illusions may be created for ends different from those of the classical psychological novelist, but they are in fact illusions rendered in prose, and thus may well be called novels in the teeth of his own reiterations that "novel" means only psychological realism. Robbe-Grillet's prose illusions are delivered in aid of his sense of the way things are, just as Thackeray's were delivered. That Thackeray thought things more reliably discernible and generally agreed-upon, while Robbe-Grillet sees only things and no necessary agreement about meanings, does not affect their shared status as novelists, whatever their different manners may tell us about nineteenth- and twentieth-century notions of reality. Though RobbeGrillet disputes and defies Thackeray's brand of prose realistic convention, he is no less concerned with reality in the larger, non-literary sense of the word-concerned, that is, to insist and demonstrate that such a reality as Thackeray's cannot be. Phenomenology's illusions of the real are not literary realism's.

Where Robbe-Grillet works to divorce his fiction entirely from realism's conventions, Muriel Spark only seems to want such a divorce. In a way, in fact, her novels are conventionally realistic. They move through separable phases of action so that eventually one may speak of beginning, middle end; of process and outcome. They are filled with what we customarily describe as characters, a part of whose familiarity is that they develop and/or reveal more and more of their motivation and particular psychology (though usually not all of these). Her novels are told by traditional third- and first-person narrators. The books operate on the assumption that we're out here banking on a fixed and reliable point of view in there to tell us how things were and how established characters saw things through to discussable conclusions. One may, in sum, speak of motivation, progress, development and outcome in these novels.

To say no more, however, would be to fail Muriel Spark in two ways. On one hand, we would ignore the different effects of her and Robbe-Grillet's sharp depictions of image, setting, character. On the other hand, we would slight the considerable discrepancy between her and most realists. For if she is not RobbeGrillet, neither is she Arnold Bennett. What else, then, shall we say of her work?

As might be expected, what remains to be said makes all the difference and 
accounts for her uniqueness. For in her own way, Muriel Spark holds out against the conventions of an exclusive realism as strenuously as does Robbe-Grillet. Signs of her opposition are in fact prominent in all twelve of her novels, and are the reason for her finding disfavor in the eyes of many readers. This uniqueness may be spoken of as an attention paid to the other-worldly, as a penchant for fantasy, as a refusal to explain, or as any number of other indications that things are not quite normal in her books, where the reader's measure of normality is literary realism. And of course this deviation from the expected is more chastised than understood, accepted or applauded-predictably, since we have all been conditioned by two hundred years of literary realism. Nevertheless, such conditioning is something out of which I should like to talk readers of Muriel Spark.

Thus, when a typewriter appears to be heard operating in an adjoining room, as in The Comforters, we should: (1) assume that someone tangible and photographable is whacking away at the machine in question; (2) realize that Muriel Spark has assumed that we will make precisely that assumption; (3) not at once assume, when we catch nobody turning out the undeniably tangible copy, that the author or one of her characters is either crazy or trivially and pointlessly fantastic; (4) consider what, besides craziness or blind-alley mystification, might cause the novelist to build such fictional illusions; (5) realize that taking (4) seriously is not to betray realism or adult responsibility, but may in fact prod awake a dormant capacity to read such books as A Pilgrim's Progress and The Scarlet Letter without inquiring guiltily, irrelevantly and self-defeatingly whether these books may be read and discussed as if Trollope had written them; and (6) "take" so instinctively to such unrealistic fictional incidents as to experience all five preceding insights habitually and automatically, and to see them as properly applicable to the particular sort of illusion created by Muriel Spark. But how to reach the condition of $(6)$ ?

As I see these points, (6) will inevitably follow our coming to terms with the other five; and the first three will become happy habit when we can handle (4) and (5) convincingly-as I should like now to try doing. If, as (4) asks, we decline to throw away The Comforters and if we try instead to find out what we discern by proceeding patiently, I think we conclude that realistic and nonrealistic traits in this book, whether or not they seem to contradict each other, at least co-exist. If that co-existence spurs us to ask what might be the point, the answer is likely to be reader confusion or unfamiliarity-which may be admitted to have its own interest. And, if we then move to (5), we may well see that whatever the effect of such a blending or perhaps clashing of styles, moral concern need hardly be absent from Muriel Spark's practice.

Thus far on the rather vaguely abstract and speculative level. In fact what we are asked to accept in reading The Comforters is that literary realism is important and necessary but limited; that for the awarenesses that Muriel Spark wants to convey, she requires realism to be both complemented and opposed; that Hamlet understands Horatio and much more, whatever the genuine merits of Horatio in arranging aftermaths and narrating external happenings. A bit less metaphorically, we are asked to entertain the notion that not all effects are adequately explained 
by rationally attainable causes; that the sensibility of the author, which is notably like that of her author-character Caroline Rose, requires our vicarious identification with its ability to entertain certain questions and phenomena which in our realistic reading habits we would blush to approach seriously. In short, unless we allow ourselves the kind of novel Muriel Spark has given us, we limit ourselves to the otherwise fine imaginative enterprise involved in handling literary realism. Surely such inhibition should not be cultivated.

In practice, what the foregoing example and discussion amount to is an intimation of what we are to make of, say, the telephone calls in Memento Mori, the particulars of religious conversion in The Prime of Miss Jean Brodie and The Girls of Slender Means, the destruction of "realistic" suspense by virtue of using a flashforward device in such novels as The Driver's Seat and Not to Disturb, and the use of the dead as main characters in The Hothouse by the East River. Clearly, the author upsets what we are conditioned to think we may expect in mystery stories, tales of ratiocination, accounts of psychological development arranged to explain changes in behavior if only we will attend to what Western psychological schooling has prepared us for. Always in Muriel Spark's work there is something not only unincorporated into realistic tradition, but paradoxically forced to cooperate with that tradition. Details isolated in this paragraph all point to a consistent authorial awareness that we must indeed use our imagination and intelligence, and that the most important thing we learn thereby is the limits of reason. Thus, of course rationally conditioned persons want to find out who's calling (rather than allow themselves to attend to what the caller says), and will get the phone company to trace the call: all sensible effects have traceable connected causes, do they not? No, says Muriel Spark, they do not; or if they do have such causes they have other causes as well-and the combination of emphasis upon the limits of our knowledge and the possibility or even inevitability of more than one kind of cause is what makes these twelve novels. It should not be surprising, then, once we have put aside Dreiserian assumptions, to find that a conviction of evil can be as overpowering as a conviction of good, and can therefore motivate religious conversion. Similarly, once we have discarded our assumption that stories housing servants, jaded masters, police, questionable accumulations of large sums of money, and violent deaths signify a single kind of mystery story, we are in a position to see that Muriel Spark is interested in presenting her awareness that what is mysterious may importantly extend beyond whodunnit for what motive to the sense that events are not only sequentially perpetrated and humanly motivated (or indeed humanly accidental), but also timelessly ordained (or indeed even accomplis). And again, once imagination admits the possibility, whether solely metaphorical or also real, that eternity both exists and, as spiritual realm, includes or co-extends with the temporal, how can we be surprised to find those whom we "realistically" call dead moving and otherwise acting physically on terra firma? Should we then presume to ask why Muriel Spark wants to write this way, the answer, as when we implicitly exacted it of Thackeray and Robbe-Grillet, is that she wishes to make manifest her view of realitynot Thackeray's realism and not Robbe-Grillet's phenomenological conviction of 
the real, but her own sense of the way in which Thackeray's realism combines with Christian belief to convey what is.

Realism, then, is merely the dominant and most familiar means of setting out one brand of illusion of what is real. Robbe-Grillet and Muriel Spark, while they share certain habits of literary realists, nonetheless operate on assumptions distinct from the realist's and from each other's for the most part. And here we may perhaps return to our opening observations drawn from E. M. Forster, in order to round out this argument and end where we began.

Forster's novel showed his awareness of what seemed the impossibility of retaining a classical rationalist's faith in the mind alone, but the novel showed also Matthew Arnold's inability to recapture a former religious belief. The way out of this famous bind would be for East and West to merge in the equanimity of Professor Godbole. But of course this is exactly what the novel posits as impossible in this time and place, and the book ends in longing, hope and at most a glimmer of possibility in the liberal humanist Fielding's marriage to Stella, who is Mrs. Moore's other child and Adela Quested's disciple. But a glimmer is really all we get. Forster is a liberal Bloomsbury realist straining against his heritage and honestly shaping his book to suggest but not effect the surpassing of his own beliefs. In his novel, Mrs. Moore's idea of mystery is destroyed and not explainably replaced in the subsequent career of Miss Quested. Thus, while the reader knows Forster's desire to provide a credible or viable substitute for that sense of mystery, he knows also that Fielding and Aziz, as rationalists, persist in thinking "mystery" and "muddle" interchangeable terms of equal meaninglessness, and he knows finally that Godbole is inscrutably unique. Moreover, if we should wish to argue that Forster's very book, in demonstrating his ability to imagine such a spectrum of human possibilities (a spectrum ranging from Ronnie's harrumphing beefeating assurance to Fielding and Aziz's rationalism to Mrs. Moore to Adela Quested to extra-rational hope whispered in Fielding and Stella to Ralph's helpless openness to Godbole's paradoxically sealed transcendence)-if we suppose that such moral-aesthetic range is itself a substitute for the vanished sense of mystery, I would reply that while such art contributes to the glimmer of hope, it is nevertheless focused on characterizing, however brilliantly, assortments and degrees of opaqueness and isolation. The fineness of Forster's art is not itself a bridge or a passage, but is rather the poignant sign of what is vastly wanting. (Interestingly, those who produced the BBC television play entitled A Passage to India presumably found the whole spiritual issue so fundamentally undramatizable, at least today, that they focused upon, and ended with, the courtroom showdown. Such Procrustean obeisance to "realism," however understandable, may abet our discussion of why Muriel Spark has trouble communicating.)

A half-century later, Robbe-Grillet has simply abandoned any hope of achieving the sort of merger which Forster sought. Jealousy, La Maison de Rendez-vous and his other books all take for granted the premise of Sartre's Existentialism, that of course what is is absurd and without the possibility of yielding what used 
to be called "meaning." In the inevitably resulting total subjectivity, then, we achieve Zola's dream of total objectivity. No literary art, consequently, makes any sense except that art which assumes moral and psychic isolation beyond the recording or reciting (painstakingly, to be sure) of stuff, things, phenomena "human" or other. Robbe-Grillet's art, like Sartre's philosophy, is rooted in despair, whatever optimism may paradoxically emerge for either man from that origin. Meaning is a foolish notion, a non-notion, but in any event cannot signify beyond the individual sensibility. To become Godbole would be meaningless even if it were possible. Why play games to separate "mystery" from "muddle" (or indeed to combine the two) when all is a chaos of eaches, non-meaning impeccably languaged?

In such a context, Muriel Spark has a difficult task, we may say. In her books it is evident that "mystery" and "muddle" do not coalesce in a universal absurdity. It is also evident that these terms do not coalesce in sloppy synonymy, as for the classic old-fashioned rationalist, to signify what the mind has not yet significantly discovered, but what man will eventually know and explain because after all whatever "really" is can be mind-handled. Rather, Muriel Spark's work implicitly distinguishes between these terms, so that "muddle" may be understood to mean such things as are available to the mind and therefore potentially comprehensible by reason, but which are at present still unclear. "Mystery," on the other hand, may be taken to embrace that whole area of experience and possibility of which one may have intuitive awareness, and in which one must therefore believe, but which is no more fathomable by mind, the rational faculty, than the ability to write music belongs to bulldozers.

Operating out of such assumptions, Muriel Spark therefore uses conventions of literary realism to build our expectations and to involve us therein before she overturns these expectations by including realism's moves within a larger reality (much as Hamlet's view does not reject, but accommodates and includes, Horatio's). Being thus true to her vision means of course parting company with the Fieldings, whose liberal Western realism, for all its humanistic tolerance, supposes her to be making a distinction without a difference and indulging in wishful thinking; and it means alienating the Robbe-Grillets as well, who will have rejected not only the distinction but Fielding and Aziz's realism too. In short, Muriel Spark sets herself the chore of making illusorily real the double vision of Adela Quested and the potentiality of simultaneous vision as embodied in the attitude of Professor Godbole.

Reading Forster, Robbe-Grillet and Muriel Spark together in this way has perhaps demonstrated my conviction of how they bear upon one another as well as how they disagree in their ideas of the real. The problem is that of discovering various uniquenesses and probably of suspending various disbeliefs. In day-to-day reading, teaching, criticizing, this problem in our time remains one of distinguishing between the conventions of literary realism and what may be seen as reality.

\footnotetext{
- I am grateful to the University of Oregon's Office of Scientific and Scholarly Research for the Summer Research Award which assisted me in the writing of this paper.
} 